\title{
The sources and types of innovation knowledge in technology adoption decisions in infection prevention and control - comparative case studies of 12 NHS trusts in England
}

\author{
Y Kyratsis, ${ }^{*}$ R Ahmad, A Holmes \\ From International Conference on Prevention \& Infection Control (ICPIC 2011) \\ Geneva, Switzerland. 29 June - 2 July 2011
}

\section{Introduction / objectives}

The nature, sources and format of evidence used by managers and clinicians is important in introducing innovations in healthcare. We investigate the organisational decision making process focusing on the adoption of innovative technologies in the context of infection prevention and control (IPC) and the nature of evidence used.

\section{Methods}

Qualitative, multi-level, multiple case study design involving primary \& acute care trusts. We conducted 121 semi-structured interviews drawing on a purposive multi-level, multi-stakeholder sample. Data was analysed using an integrated approach.

\section{Results}

We mapped out 38 organisational technology selection decisions from July 2009 to August 2010. We specifically mapped the organisational adoption decisions to three types of innovation knowledge: 'awareness' (awareness that the innovation exists), 'principles' (its functioning principles) and 'how to' (information related to its practical use). The leadership role adopted by the Director of IPC and the professional background of key decision makers influenced this asymmetry to different types of knowledge considered.

\section{Conclusion}

In the commercial sector innovation adoption focuses at the individual level and majority of attention by change agencies is around awareness and how to knowledge. In

Faculty of Medicine, Imperial College London, London, UK our study we found the converse; overall less attention was given to how to knowledge at the point of innovation adoption decision and more attention was attributed to principles knowledge both by decision makers and change agents. Attending to 'how to' knowledge at decision making stage may enhance successful technology adoption and effective use. This has important implications for suppliers, managers and clinicians.

\section{Disclosure of interest}

None declared.

Published: 29 June 2011

doi:10.1186/1753-6561-5-S6-O47

Cite this article as: Kyratsis et al:: The sources and types of innovation knowledge in technology adoption decisions in infection prevention and control - comparative case studies of 12 NHS trusts in England. BMC Proceedings 2011 5(Suppl 6):O47.

Submit your next manuscript to BioMed Central and take full advantage of:

- Convenient online submission

- Thorough peer review

- No space constraints or color figure charges

- Immediate publication on acceptance

- Inclusion in PubMed, CAS, Scopus and Google Scholar

- Research which is freely available for redistribution

(c) 2011 Kyratsis et al; licensee BioMed Central Ltd. This is an open access article distributed under the terms of the Creative Commons 